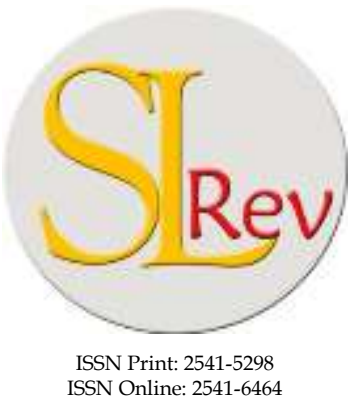

ISSN Online: $2541-646$

\section{SRIWIJAYA}

Editorial Office: Faculty of Law, Sriwijaya University

Jalan Srijaya Negara, Palembang, South Sumatra 30139, Indonesia.

Phone: +62711-580063Fax: +62711-581179

E-mail: sriwijayalawreview@unsri.ac.id|sriwijayalawreview@gmail.com

Website: http://journal.fh.unsri.ac.id/index.php/sriwijayalawreview

\title{
Foreign Migrants Trespassing in Sabah Forest Reserves: A Legal Discourse
}

\author{
Rohani Abdul Rahim, ${ }^{\mathrm{a}^{*}}$ Muhamamd Afiq Ahmad Tajuddin, ${ }^{\mathrm{a}}$ Rovina Intung, ${ }^{\mathrm{a}}$ Azizah Landa, ${ }^{\mathrm{a}}$ \\ and Herlina Makanah ${ }^{\mathrm{a}}$
}

$a^{*}$ Former Senior Lecturer, Faculty of Law, Universiti Kebangsaan Malaysia, Malaysia. E-mail: drrohani60@gmail.com

\begin{tabular}{|c|c|}
\hline ticle & et \\
\hline Keywords: & According to Sabah Forestry Enactment 1968 , Yang di-Pertua Negeri \\
\hline $\begin{array}{l}\begin{array}{l}\text { Forest Reserve, Foreign } \\
\text { Migrants; } \\
\text { trespassing. }\end{array} \\
\text { Illegal } \\
\text { Article History } \\
\text { Received: Oct 29, 2020; } \\
\text { Reviewed: Jan 23, 2021; } \\
\text { Accepted: Jan 30, 2021; } \\
\text { Published: Jan 31, 2021. }\end{array}$ & $\begin{array}{l}\text { Sabah is given the power to reserves forests for various purposes including } \\
\text { commercial, protection, domestic and others. Sabah Forestry Department } \\
\text { is entrusted with proper and efficient planning, and implementation of } \\
\text { State forest resources management (SFM) to comply with the sustainable } \\
\text { forest principles. It achieves to manage forest resources towards } \\
\text { sustainable and profitable forest governance. However, Sabah forest } \\
\text { reserves were threatened by illegal trespassing by foreign migrants to } \\
\text { possess forest produce unlawfully and to occupy State land illegally. This }\end{array}$ \\
\hline $\begin{array}{l}\text { DOI: } \\
\text { 10.28946/slrev.Vol5.Iss1. } \\
\text { 977.pp101-115 }\end{array}$ & $\begin{array}{l}\text { foreign migrants, the offences committed by foreign migrant activities in } \\
\text { the forest reserves, violation of specific legislation such as the Immigration } \\
\text { Act } 1959 / 63 \text { and the Forest Enactment } 1968 \text {. The qualitative legal research } \\
\text { methodology was used to understand the issues at hand, the existing } \\
\text { applicable laws and the legal implications for such illegal activities in } \\
\text { these forest reserves. Secondary data found in the legislation, journals, } \\
\text { annual report, and law publication were collected, reviewed, analysed, and } \\
\text { discussed to understand its legal implications better. Thus, efforts to } \\
\text { expose these illegal activities by foreign migrants is essential to ensure } \\
\text { Sabah Forest Reserves can continuously be maintained and not destroyed } \\
\text { at the hand of illegal foreign trespassers. Employers should also be made } \\
\text { responsible for their involvement in trafficked or smuggled illegal } \\
\text { migrants as workers and simultaneously, conduct illegal activities to deceit } \\
\text { the State Forestry efforts and developmental planning in Sabah. }\end{array}$ \\
\hline \multicolumn{2}{|c|}{$\begin{array}{l}\text { (C)2021; This is an Open Access Research distributed under the term of the Creative Commons Attribution Li- } \\
\text { cense (https://Creativecommons.org/licences/by/4.0), which permits unrestricted use, distribution, and repro- } \\
\text { duction in any medium, provided the original works are appropriately cited. }\end{array}$} \\
\hline
\end{tabular}

\section{INTRODUCTION}

Sabah State Government gazetted 3.61 million hectares of Sabah Forest as a forest reserve and classified them into seven class type as determined in Table 2. These forest reserves are gazette 
into two categories that are about 1.29 million hectares (35.50\%) as forest reserves for environmental protection, and 2.31 million (about 70\%) hectares is classified as Production Forest and manages according to Forest Management Sustainability Principles to produce timber and other forest resources. The Forest Management sustainable forestry planning follows the 3-tiered approach, as shown in Table 1.

Table 1, The 3-Tiered Sustainable Forest Management

\begin{tabular}{lll}
\hline Management Level & Planning Period & Main Components \\
\hline Forestry Sector & $10-20$ years & $\begin{array}{l}\text { Forestry Sector Plan; Forest } \\
\text { Policy; Legislation }\end{array}$ \\
\hline Forest Management Unit & $5-10$ years & $\begin{array}{l}\text { Forest Zoning; Resource Inven- } \\
\text { tory; Output Control }\end{array}$ \\
& & $\begin{array}{l}\text { Harvesting and Silviculture; } \\
\text { Non-timber Forest products; } \\
\text { Resource Accounting }\end{array}$ \\
\hline
\end{tabular}

Source: Sabah Forestry Department $2017^{1}$

The planning was developed for the purpose of among others: 1) to ensure the socioeconomic and environmental benefits from the forests are maintained in perpetuity; 2) extend the Deramakot Forest Reserve (DFR) management planning model to all the other Commercial Forest Reserves in Sabah; 3) Implement SFM in all forest management units, each of which should comprise at least 100,000 ha of the commercial forest; 4) Ensure that the management plans for all FMUs are completed with the appropriate prescriptions for field implementation.

The types and distribution of the forest areas can be seen classified as in Table 2.

Table 2, Area of Reserved Forest (2018)

\begin{tabular}{lll}
\hline Class & Type of Reserved Forest & Approximate Area (Ha) \\
\hline Class I & Protection Forest & $1,386,614.62$ \\
Class II & Commercial Forest & $1,659,899.15$ \\
Class III & Domestic Forest & $4,656.00$ \\
Class IV & Amenity Forest & $11,386.45$ \\
Class V & Mangrove Forest & $232,039.27$ \\
Class VI & Virgin Jungle Forest & $106,911.614$ \\
Class VII & Wildlife Reserves & $139,240.97$ \\
\hline & Grand Total & $\mathbf{3 , 5 4 0 , 7 4 8 . 8 7 4}$ \\
\hline
\end{tabular}

Source: Sabah Forestry Department, $2018^{2}$

Table 3 classifies forest areas' distribution according to their primary functions for 2014 , 2015, 2016, 2017 and 2018. The forest reserves functions as protection, commercial, domestic, amenity, mangrove and virgin jungle. Trespassing in these forest reserves will affect their purpose of reservations and deny the state developmental, conservations and commercial planning particularly.

Table 3,

Comparative Classification of Forest Reserve by Function for 2014, 2015, 2016, 2017 \& 2018 Class Type of Forest

Approximate Area (Ha)

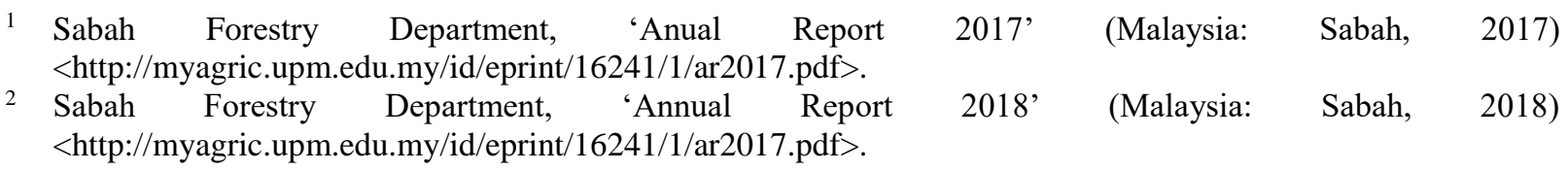




\begin{tabular}{lllllll}
\hline & Reserved & $\mathbf{2 0 1 4}$ & $\mathbf{2 0 1 5}$ & $\mathbf{2 0 1 6}$ & $\mathbf{2 0 1 7}$ & $\mathbf{2 0 1 8}$ \\
\hline Class I & Protection Forest & $1,038,890$ & $1,260,098$ & $1,353,677.66$ & $1,386,614.620$ & $1,386,614.620$ \\
\hline Class II & Commercial Forest & $2,033,183$ & $1,750,521$ & $1,668,272.95$ & $1,659,899.950$ & $1,1659,899.950$ \\
\hline Class III & Domestic Forest & $4,673.00$ & $4,673.00$ & $4,673.00$ & $4,656.000$ & $4,656.000$ \\
\hline Class IV & Amenity Forest & $12,409.45$ & $11,149.67$ & $11,386.45$ & $11,386.450$ & $11,386.450$ \\
\hline Class V & Mangrove Forest & $281,374.56$ & $280,002.27$ & $256,009.27$ & $232,039.270$ & $232,039.270$ \\
\hline Class VI & Virgin Jungle Forest & $106,801.14$ & $106,801.32$ & $107,013.914$ & $106,911.614$ & $106,911.614$ \\
\hline Class VII & Wildlife Reserves & $137,735.00$ & $137,991.00$ & $139,240.97$ & $139,240.970$ & $139,240.970$ \\
\hline \multicolumn{2}{c}{ Grand Total } & $3,651,066.15$ & $3,551,246.76$ & $3,540,274.14$ & $3,540,748.874$ & $3,540,748.874$ \\
\hline
\end{tabular}

Source: Sabah Forestry Department, 2018

In Sabah, the Forestry Department has been entrusted with managing and controlling forest and forestry activities. Sabah is located on the northern tip of Borneo Island and is among the largest timber producers in Malaysia even though it is the second-largest state in Malaysia. It also possesses the oldest tropical rainforests and the world's richest biodiversity. Restoring forest generates a wide range of benefits to human health and includes absorption of greenhouse gases and capture of pollutants, infectious disease modulation, and local cooling. ${ }^{3}$

The entire state forests are monitored by the Forestry Department in each district of Tawau, Kunak, Serundong, Lahad Datu, Semporna, Kalabakan, Ulu Segama-Malua, Sandakan, Beluran, Telupid, Tongod, Deramakot, Kinabatangan, Keningau, Nabawan, Sook, Tambunan, Tenom, Tibow, Kudat, Pitas, Kota Belud, Kota Marudu, Kota Kinabalu, Beaufort, Sipitang, Ranau. Despite the strict security to protect forest products, forest violation is still occurring either by locals or foreign migrants. It happens due to the richness of timber products of Sabah's forests. The Annual Sabah Forestry Department Report 2018 stated in Table 4 that the state forests' total output was RM195,108,881.36. This high revenue has drawn interest mainly from foreign migrants to trespass and exhume the forest products. Most of them are illegal workers because they do not possess any valid travelling documents and work permit. ${ }^{4}$

Table 4, Forest Revenue 2018

\begin{tabular}{lc}
\hline Item & Amount (Milion RM) \\
\hline Royalty and fees on forest produce & $144,613,810.14$ \\
Royalty on the export of processed timber & $7,582,450.96$ \\
The premium on round logs & $15,533,996.38$ \\
Timber scaling and grading, inspection \& marketing fees and other services & $817,088.33$ \\
Vehicles and logging equipment fees \& processing fees & $1,880,705.00$ \\
Fees for issuance and renewal of licenses and permits & $6,454,098.43$ \\
Other timber produces & $18,226,732.12$ \\
\hline Total & $\mathbf{1 9 5 , 1 0 8 , 8 8 1 . 3 6}$ \\
\hline
\end{tabular}

Source: Forest Revenue and Expenditure 2018, Sabah Forestry Department

\section{RESEARCH METHODS}

The research used a qualitative research method that involved data collections of primary data: the co-writer being the forestry officer can describe in detail some of the processes involved in

3 Megan K Suter and others, 'Association Between Work in Deforested, Compared to Forested, Areas and Human Heat Strain: An Experimental Study in A Rural Tropical Environment', Environmental Research Letters, 14.8 (2019), 084012.

4 Aiman Aizuddin Junaidi and others, 'Trafficking In Persons Laws And Border Control Challenges In Malaysia: Asean Discourse' (Sciendo, 2019), pp. 27-35 <https://doi.org/10.1515/9783110678666-006>. 
illegal immigrants trespassing prevention efforts. ${ }^{5}$ They were arrested for infringing the Immigration laws, Sabah Forestry Enactment provisions and other laws as discussed in this article. While secondary data were obtained from journals articles, Sabah Forestry Department annual reports, printed legislation (Acts and Enactment), and law books. In-depth descriptions and reviews of these data and information provide better understandings of the social, legal issues at hand and how the Sabah Forestry Department carried out operations and arrested the trespassers for carrying out forest criminal activities? Legal research method analysis ${ }^{6}$ and interpretations were made on various laws determining the offences and the sanctions as penalties for illegal immigrants' wrongdoing, that are not only for smuggling and trafficking themselves into Sabah but also causing destructions and extracting illegally Sabah valuable forest resources.

\section{ANALYSIS AND DISCUSSION \\ Illegal Migrant}

United Nations in 2019 stated that there were more 272 million international migrants. While 83.6.9 million live in Asia, 164 million became foreign workers, and 400,000 are illegal migrants (Pendatang Tanpa Izin -PATI). It proves that economic growth and social development of developing countries attract migrants from other countries. The situation worsens with the arrival of illegal migrants into Sabah. ${ }^{7}$

Sabah's strategic geographical position is the main factor of the foreign migrant influx in Sabah. The migrant population in Sabah increased drastically from 1963 until 2012 (The Star Online, 2013). The majority of them are from Indonesia and the Philippines. The Indonesians who wish to commute to Malaysia choose Nunukan and Tarakan District as their main transit points. ${ }^{8}$ The influx of foreign migrants legally or illegally in the country has led to many problems that cause threats to this country's welfare and public affairs. Higher crime rates like robbery, theft, murder, burglary and other crimes are identified and the locals as their main target. The severely increased trend includes cross-border crime and transnational crime, including trafficking of firearms, drugs, vehicles and gambling. Their capability to violate the laws of Malaysia has also threatened the security and sovereignty of the country. The most worrying is the ability of the foreign migrants to enter Malaysia illegally and become "prohibited migrant" according to the Immigration Act 1963 (this was explained further in the following discussions). Who are these illegal migrants? Azizah Kassim defines illegal migrant to include

“1) A foreigner who enters a country without permit or pass; 2) A foreigner who slips into a country through the undisclosed channel; 3) A foreigner who enters a country legally but stays on without renewing the permit or pass; 4) A contract workers (expatriate/semi-skilled and skilled) who violates the

5 Lisa Webley, Qualitative Approaches To Empirical Legal Research, ed. by Peter Cane and Herbert M. Kritzer, 1st edn (Oxford University Press, 2010) <https://www.researchgate.net/publication/259339842_Chapter_38_Qualitative_Approaches_to_Empirical_Le gal_Research>.

6 Mike McConville and Wing Hong Chui, Research Methods for Law, 2nd edn (United Kingdom: Edinburgh University Press Ltd, 2017).

7 Deniz Sert, 'Harald Kleinschmidt (Ed), Migration, Regional Integration and Human Security: The Formation and Maintenance of Transnational Spaces', Millennium : Journal of International Studies, 35.3 (2007), 781-84 <https://doi.org/10.1177/03058298070350030710>.

8 Ramli Dollah and Ahmad Mosfi Mohamad, 'Malaysia-Indonesia Barter Trade: Opportunities and Challenges', JATI-Journal of Southeast Asian Studies, 12 (2007), 83-106. 
work permit by changing their work or their employer; 5) A foreigner who misuses the pass visit, for instance, those who enter on tourist or student visa but abuses the given visa by staying on to do other things; 6) Those who possess fake document or legal document but entered the country through illegal means; 7) A foreign worker who fails to renew his or her working permit; 8) A refugee who fails to renew his or her yearly IMM13 pass.",

\section{Migrating With Purpose Issuance of Entry Document}

International migrants that enter Malaysia were signified according to the purpose of their entrance. Some came to work, for education, to establish trade or even to reside. However, those without proper documents may face legal action for overstaying or entering Malaysia illegally and considered "prohibited persons" according to Section 8, Immigration Act, 1959/63 (Act 155). The Immigration Department will issue proper documents for the purpose of the entrance as determined before their entrance. Table 5 laid down the types of entrance documents produced by the Immigration Department as a means of control ${ }^{10}$ while staying in this country.

Table 5, Types of Border Regulated Documents granted to International Migrants

\begin{tabular}{l} 
Types \\
\hline Permanent Residents \\
Spouse Visa \\
Expatriates \\
Dependent Pass \\
Social Visit Pass \\
Border Pass (Pas Lintas \\
Batas) \\
Foreign skilled workers \\
Unskilled/low-skilled and \\
semi-skilled workers \\
(contract workers)
\end{tabular}

Issued permanent residency cards (MyPR Kad)

Reside and work indefinitely

Spouses of Malaysian citizens with foreign nationality

Issued a renewable spouse permit for a period of 6-24 months

Require a work permit to work

Include professional and technical migrant workers earning a monthly salary of not less than MYR3000.

Need to be sponsored by their employers.

Issued Employment Pass - for at least a 2 year employment contract.

Allowed to bring dependents who are issued a Dependent Pass (immediate family) or Social Visit Pass (relatives).

Not allowed to obtain citizenship through marriage with a Malaysian citizen.

Visa for children and spouses of expatriates.

Issued to close family members such as parents or in-laws of those who hold Employment Passes.

Not allowed to work.

Issued to citizens of neighbouring countries, Indonesia (North Kalimantan) and Thailand (Southern Thailand) that share the land with Malaysia. Pass holders are allowed multiple entries and stay for a maximum of 30 days per visit but are not permitted to work in Malaysia. Includes professional and technical migrant workers Issued Visit Pass for Professional Employment for short-term contracts of less than a year.

Salary is set below MYR2500

Issued a Visit Pass for Temporary Employment (VPTE) for initially three years and extendable for two more years $(1+1)$. Must be renewed annually.

Restrictions apply on the origin, the sectors in which they work and their age.

9 Azizah Kassim, 'The Unwelcome Guests: Indonesian Immigrants and Lamaysian Public Responses', Japanese Journal of Southeast Asian Studies, 25.265-278 (1987) <https://kyoto-seas.org/pdf/25/2/250205.pdf>.

10 Joseph Trawicki Anderson, 'Managing Labour Migration in Malaysia: Foreign Workers and The Challenges of “Control” Beyond Liberal Democracies', Third World Quarterly, 42.1 (2021), 86-104. 


\begin{tabular}{ll} 
& Not allowed to bring dependents. \\
& Not allowed to marry and reproduce in Malaysia. \\
Travel to Malaysia for holiday purposes using tourist visas & Not allowed to reside or work \\
*Indonesians are permitted to travel to Malaysia visa-free for 30 days. & \\
& Include students enrolled in higher education institutions. \\
Length of stay is based on the period of study as stated on the visas. & Require a work permit to work in Malaysia \\
Foreign students & Issued Social Visit Pass with a multiple entry visa \\
Moreigners under the & Allowed to stay as long as they like (initially for a period of 10 years). \\
Home Programme & Issued UNHCR (UN Refugee Agency) refugee cards \\
Refugees & Allowed to reside but not to work until resettlement (conditions set by \\
& UNHCR) \\
\hline & Sources: Kanapathy (2008a, pp. 335-337); Kaur (2015)
\end{tabular}

\section{Forest Trespassing}

Sabah Forest Enactment 1968 defines forest trespass to include the entrance into any Sabah Forest reserves without specified authorities' permission. According to Joseph Tangah, assessment on Sabah forest coverage in 2008 found that around 3,300 hectares or approximately $0.97-1$ per cent of the mangroves forest reserves were trespassed or illegally exploited (Utusan Borneo, January 9 2016). While according to Tacconi ${ }^{12}$ forest trespass activities mean "[They] include the acts related to the establishment of land rights, corrupt activities to acquire forest concessions, unlawful activities at all stages of forest management and the forest good production chain, from the planning stage to harvesting and transport of raw materials and finished products, to financial management."

Malaysia National Land Code also define trespass on reserve land in Section 425(1) which provides that "any person who, without lawful authority (a) occupies, or erects any building on, any State land, reserved land or mining land, or (b) clears, ploughs, digs, encloses or cultivates any such land or part thereof; or (c) cuts or removes any timber or products on or from such land, shall be guilty of an offence, and liable on conviction to a fine not exceeding ten thousand ringgit, or imprisonment for a term not exceeding one year.

In consequence, the following provisions apply as mentioned in the sub-section (1A) that Any person who abets the commission of an offence under subsection (1) shall be guilty of an offence, and liable on conviction to a fine not exceeding ten thousand ringgit, or imprisonment for a term not exceeding one year, or to both; (2) For the purpose of this section, State land shall include all land held by or on behalf of Federal or State Government a local authority or a statutory authority exercising powers vested in it by Federal or State law."

The Federal government plans to "increase the fine from RM10,000 to RM30,000 for illegal trespassing, and an increase of the fine from RM500,000 to RM5mil for those found to

11 Amarjit Kaur, Labour in Malaysia: Flexibility, Policy-Making and Regulated Borders, ed. by Meredith L Weiss (Oxford, United Kingdom: Routledge, 2015) <https://hdl.handle.net/1959.11/17636>.

12 Luca Tacconi, Illegal Logging: Law Enforcement, Livelihoods and The Timber Trade (London: Earthscan Forest Library, 2007). 
have unlawful possession of forest produce" (National Forestry Act 1984). ${ }^{13}$ However, Sabah and Sarawak administered these issues based on separate Land Ordinance (Cap.68).

Migration management is a complex and challenging responsibility, combined with geopolitical and cultural factors that are very difficult for authorities to control foreigners' flow, especially illegal immigrants. ${ }^{14}$ Forest trespass by foreign migrants has affected the economy, security and national legislation in Sabah. In Sabah, the two predominant migrants are the Indonesians (85\%) and the Filipinos (15\%) due to close geographical proximity between Sulawesi and North Kalimantan, Indonesia and Southern Philippines. ${ }^{15}$ According to Juppenlatz, ${ }^{16}$ the problem of land trespass is closely linked to several matters such as economic development, the standard of living and the urbanization process experienced by the countries concerned.

\section{Arrest Statistics}

From 2011 to 2013, the Sabah Forestry Department carried out the operation that resulted in 92 arrests $(60 \%)$ of foreign workers and $69(40 \%)$ were locals. Arrests of foreign migrants were high as the forest was identified as a hiding place for them while escaping from any immigrants (PATI) arrest operations by the authorities. In contrast, the highest arrests of foreign migrants were in Kalabakan District, where 16 migrants were arrested for carrying out forest trespass activities. A total of 1,390 arrests conducted on the illegal migrants and locals for forest trespassing since 2003. It can be observed in Table 6 .

Table 6, Total Arrest of Forest Trespassers (2003-2013)

\begin{tabular}{cccc}
\hline Years & Illegal Migrants & Locals & Total \\
\hline $2003-2006$ & 471 & 261 & 732 \\
$2007-2010$ & 274 & 218 & 492 \\
$2011-2013$ & 92 & 69 & 166 \\
\hline TOTAL & $\mathbf{8 3 7}(\mathbf{6 0 \%})$ & $\mathbf{5 4 8}(\mathbf{4 0 \%})$ & $\mathbf{1 , 3 9 0}$ \\
\hline
\end{tabular}

Source: Annual Report 2013, Sabah Forestry Department

Table 7 shows the number of arrest by districts in Sabah. However, the number is not reflective of the problem at hand because the nature and location of the crime are conducive for the illegal migrant to escape into the deep and vast forest whenever the Forestry Department conduct operations. Thus, this sometimes hinders enforcement efforts to prevent illegal migrants trespassing activities.

Table 7, Arrests and Citizenship Status by Districts 2011-2013

\begin{tabular}{|c|c|c|c|c|}
\hline \multirow[b]{2}{*}{ District } & \multirow[b]{2}{*}{$\begin{array}{c}\text { Area Trespassed } \\
\text { (Ha) }\end{array}$} & \multirow[b]{2}{*}{$\begin{array}{l}\text { New Trespass } \\
\text { (Ha) }\end{array}$} & \multicolumn{2}{|l|}{ Arrests } \\
\hline & & & Illegal Immigrants & Locals \\
\hline Kunak & $5,641.80$ & - & - & - \\
\hline Semporna & $3,666.12$ & - & 8 & 21 \\
\hline
\end{tabular}

13 Martin Carvalho and others, 'Xavier: Govt Considering Stiffer Penalties for Illegal Trespassing, Unlawful Possession of Forest Produce', Nation, $2019<$ https://www.thestar.com.my/news/nation/2019/12/04/xaviergovt-considering-stiffer-penalties-for-illegal-trespassing-unlawful-possession-of-forest-produce> [accessed 4 December 2019].

14 Kanapathy and Vijayakumari, Controlling Irregular MIgration: The Malaysian Experience (International Labour Organization, 2008).

15 National Population and Family Development Board, Laporan Kajian Pekerja Indonesia Di Bahagian Tawau, Sabah (Kuala Lumpur, Malaysia: National Population and Family Development Board, 2014).

16 Morris Juppenlatz, Cities in Transformation: The Urban Squatter Problem of the Developing World (University of Queensland Press, 1970). 


\begin{tabular}{lllll} 
Tawau & $3,317.00$ & - & 14 & 2 \\
Lahad Datu & $2,234.60$ & 2.5 & 14 & 1 \\
Ulu Segama-Malua & 437 & 20 & 5 & - \\
Kalabakan & 2 & - & 16 & 3 \\
Serudong & 8 & - & - & - \\
Tongod & $2,247.00$ & - & 7 & 3 \\
Sandakan & 471.07 & 9.1 & 1 & 11 \\
Beluran & 269 & - & 2 & - \\
Telupid & 136.96 & - & - & - \\
Deramakot & 35.58 & - & - & 1 \\
Kinabatangan & 369.72 & - & 5 & - \\
Sook & 110 & - & 2 & - \\
Tenom & 15 & - & - & 1 \\
Keningau & 121,44 & - & - & 6 \\
Kota Kinabalu & 244 & 63.32 & - & 2 \\
Ranau & 92 & - & - & - \\
Beaufort & 10 & - & - & 3 \\
Kudat & $1,530.00$ & - & 5 & 8 \\
Pitas & 102 & - & - & 6 \\
Nabawan & & 1.6 & 11 & - \\
Tibow & 2.5 & - & 5 & $\mathbf{6 9}$ \\
\hline Total & $\mathbf{2 1 , 0 6 7 . 7 9}$ & $\mathbf{9 6 . 5}$ & $\mathbf{9 7}$ & 1 \\
\hline
\end{tabular}

Source: Sabah Forestry Department, 2015

\section{Forestry Related Legislations}

There are many forestry-related legislation enacted for various purposes including Land alienation and registration, management and licensing of resources excavations, environmental preservations and forestry management.

\section{Forestry Enactment 1968 And Forest Regulation 1969}

Forestry Enactment 1968 And Forest Regulation 1969 are used as guidelines to gazette the forest reserves, usage and the monitoring and management timbers, and transportation of forest resources from the forest in state land. These legal provisions are established after Sabah forest state policy introduced. While the Land Ordinance has provisions that allow state land to be alienated, activities to transport the forest resources are in Forestry Enactment.

Table 8 refers to the enforcement of Forestry Enactment, 1968, that provides categories of Forest offences stated in Section 20 (1)(c) till Section 35. They are offences to breach the protection provisions, such as destroying the forest reserves using fire, prohibited activities on the forest reserves, illegal logging, transporting out the forest resources, cutting down trees of less than the diameter limit, and being penalized with a fine and imprisonment. While offences such as unlawful entrance, destroying the fences or any forestry signboard shall be penalized with a fine. Section 30 provide, "conducting fraud, concealment of evidence and receiving prohibited forest resources is also punishable by a fine and imprisonment. In addition to fines and imprisonment, Forest Enactment authorizes the court to order license revocation, payment of fees to legalize any acts, compensation of 10 times the value of forest products removed or damaged" (Act No. 2 of 1968, Section 34). There is also provision for a forest offence ("entering an area that has been closed, practising shifting cultivation" (Section 20 (c)), subject to the payment of the fine provided under this offence (Section 35). 
According to the Sabah Forestry Department annual report 2014, a total of 146 cases of forest trespass have been reported. However, the report was highest in 2010 of 221 cases. Trespass of forest reserves involves offences such as breach of license conditions (51\%), illegal possession $(21 \%)$, illegal logging in state land $(11 \%)$, illegal cultivation in forest reserve $(9 \%)$, illegal logging in forest reserve (7\%), evasion of paying royalty $(1 \%)$ and there was no case on the illegal entry in forest reserves (0\%). Besides, theft of Agarwood (Gaharu; incensed wood) also happens because of their high value in the international market. According to the Forestry Department in the years 2011-2014, 481 kilograms of Agarwood has been spotted and is believed to be done by illegal immigrants in the state forest. ${ }^{17}$

Table 8: Categories of Forest Offences (2018)

\begin{tabular}{ll}
\hline Forest Offences & Cases \\
\hline (Section 20) Forest Enactment 1968: Illegal Logging in the forest reserve & 6 \\
(Section 23) Forest Enactment 1968: Illegal Logging in Stateland & 8 \\
(Section 30(1)(g) Forest Enactment 1968: Illegal Possession & 25 \\
Royalty Evasion & 0 \\
Illegal Entry of Forest Reserve & 0 \\
Illegal Cultivation in Forest Reserve & 6 \\
Others (Breach of license conditions, etc.) & 89 \\
\hline Total & 134 \\
\hline
\end{tabular}

Source: Sabah Forestry Department, 2018

\section{National Land Code}

According to the National Land Code that applies to the whole of Malaysia, including Sabah, anyone is prohibited from using state land reserved land and mining land for any purposes without any authorities from the state. "State land shall include all land held by or on behalf of Federal or State Government a local authority or a statutory authority exercising powers vested in it by Federal or State law." Otherwise, they were regarded as trespassers and exposed to State authorities' legal action since land matters are State matter. Those found guilty for these offences will be liable to a "fine not exceeding ten thousand ringgit, or imprisonment for a term not exceeding one year." (1A) "Any person who abets the commission of an offence under subsection (1) shall be guilty of an offence, liable on conviction to a fine not exceeding ten thousand ringgit, or imprisonment for a term not exceeding one year, or to both."

Persons who can be subjected to these sanctions include those who illegally "occupy, erects any building or state land, reserved land or mining land, or clears, ploughs, digs, encloses or cultivates any such land or part thereof or those persons whom cuts or removes any timber or products on or from such land." While Section 425A of National Land Code provides further on the use or occupying of the air space above State land or reserved land by erecting, maintaining or occupying a roof, canopy, bridge or any other structure without lawful authority "shall be liable on conviction to a fine not exceeding two thousand ringgit, or to imprisonment for a term not exceeding six months, or to both."

\section{Environmental Quality Act, 1974 (Act 127)}

The Act provide provisions that prohibit any activities that cause pollution to various "elements" such as water, atmosphere, soil, vegetation, climate, sound, odour, aesthetics, fish

17 Carvalho and others. 
and wildlife, that would affect the "environment", that are the physical factors of the surroundings of the human beings including land, water, atmosphere, climate, sound, odour, taste, the biological factors of animals and plants and the social factor of aesthetics. These activities produce "pollutant" in the forms of any substance "whether liquid, solid or gaseous which directly or indirectly (a) alters the quality of any segment or element of the receiving environment to affect any beneficial use adversely; or (b) is hazardous or potentially hazardous to health; and includes objectionable odours, radio-activity, noise, temperature change or physical, chemical or biological change to any segment or element of the environment." As a result, it causes "pollution" to the environment. It means it will cause any "direct or indirect alteration of the physical, thermal, chemical, biological, or radioactive properties of any part of the environment by discharging, emitting, or depositing wastes to affect any beneficial use adversely, to cause a condition which is hazardous or potentially hazardous to public health, safety, or welfare, or to animals, birds, wildlife, fish or aquatic life, or to plants or to cause a contravention of any condition, limitation, or restriction to which a license" under section 2 of the Act.

The illegal migrants will be involved when unlicensed or licensed local employers employed them to extract resources and do logging, which will significantly affect the environment. The Director may conduct prosecutions in respect of offences committed under this Act or regulations. General or any officer duly authorized in writing by him or by any local authority officer to which any powers has been delegated under the Act (Section 44). These local trespassers will have to face penalties such as the recovery of cost and expenses to take such the necessary action to remove, disperse, destroy or mitigate the pollution, and compounding such offences.

\section{Immigration Act 1959/63 ( Act 155)}

Act 155 consists of a few aspects focused on the issues of migrant trespass onto the Sabah forest reserves. These are discussed as follows;

\section{Legal Entry and Exit- Legal Migrants}

Foreign migrants are expected to enter any state of Malaysia, including Sabah according to approved routes at the approved and declare such "immigration control posts, authorized landing places, authorized airports, or authorized entry points unless compelled by accident or other reasonable cause" (Section 5(1)). Only those who have a valid Entry Permit lawfully issued to him; his name is endorsed upon a valid Entry Permit under section 12 "the holder of the permit; in possession of a valid Pass lawfully issued to him to enter Malaysia or exempted" according to Section 55. Illegal entry is an "offence and shall upon conviction, be liable to a fine not exceeding ten thousand ringgit or to imprisonment for a term not exceeding five years or to both, and shall also be liable to whipping of not more than six strokes."

\section{Prohibited Migrants}

Among those migrants prohibited to enter Malaysia concerning this topic of discussion, (a) any person whose entry into Malaysia is, or at the time of his entry was, unlawful under this or any other written law for the time being in force; and (b) any person who, being required by any written law for the time being in force to have valid travel documents, does not have 
those documents or has forged or altered travel documents or travel documents which do not fully comply with any such written law. In cases of trafficking and smuggling ${ }^{18}$ for the purpose of

"(a) any prostitute, or any person, who is living on or receiving, or who, before entering Malaysia, lived on or received, the proceeds of prostitution; (b) any person who procures or attempts to bring into Malaysia prostitutes or women or girls for prostitution or other immoral purposes."(Section 8, Immigration Act 1959/63).

\section{Removal of illegal migrants}

a) "Any person who is convicted of an offence under section 5, 6, 8 or 9 shall be liable to be removed from Malaysia by Order of The Director General (Section 32(1) provided he/she is a citizen." b) "If during the examination of any person arriving in Malaysia or after such enquiry as may be necessary the person is found to be a prohibited immigrant, the Director-General shall, subject to any regulations made under this Act, prohibit the person from disembarking or may in his discretion detain him at an immigration depot or other place designated by the Director-General until an opportunity arises to return him to his place of embarkation or the country of his birth or citizenship." (Section 31); c) "Removal of persons unlawfully remaining in Malaysia because of section 9, 15 or 60 the person shall, whether or not any proceedings are taken against him, be removed from Malaysia by order of the Director-General." (Section 33); d) "Suppose any person is ordered to be removed from Malaysia under this Act. In that case, such a person may be detained in custody for such period as may be necessary for making arrangements for his/her removal. Further detained in custody in pursuance of an order made by the Director-General can found in Sub-section of (2), (3) of Section 32. Any person reasonably believed to be a person liable to removal from Malaysia under this Act may be arrested without warrant by any immigration officer generally or specially authorized by the Director-General in that behalf or by a senior police officer and maybe detained in any prison, police station or immigration depot for a period not exceeding thirty days pending a decision as to whether an order for his removal should be made" (Section 35). "Any person having been lawfully removed or otherwise sent out of Malaysia, unlawfully enters Malaysia or unlawfully resides in Malaysia shall be guilty of an offence and shall, on conviction, be liable to a fine not exceeding ten thousand ringgit or to imprisonment for a term not exceeding five years or to both and shall also be liable to whipping of not more than six strokes, and shall, in addition to any penalty for the offence, be removed or again removed, as the case may be, from Malaysia." (Section 36).

\section{Penalties for Immigration Offences}

Act 155 empowers the immigration authorities in managing border controls, issuance of visas, temporary passes and return of International Migrants. Therefore, foreign migrants are subject to this Act which allocates the sentences according to the legislation in the context of immigration to prevent other arising problems from the illegal admission.

Table 9 simplify and provide descriptions and explanation about the illegal entry offences or trespassing activities of illegal migrants that enter and stay in Malaysia against the Immigration Act1959/1963 (Act 155) provisions as clarify earlier. For these offences conducted against Section 5(2), Section 6 (1)(c), Section 8, Section 9, Section 15 and Section 39(b), various sanctions in the forms of fines, imprisonment and whipping will be enforced when convicted.

Table 9, Illegal Entry Offences And Penalties

\begin{tabular}{lll}
\hline Section & Offences & Sanctions \\
\hline Section 5(2) & $\begin{array}{l}\text { Entry into or departure from Malaysia } \\
\text { prescribe approved Gazette routes and } \\
\text { declare such immigration control posts, } \\
\text { landing places, airports or points of } \\
\text { entry }\end{array}$ & $\begin{array}{l}\text { Fine up to RM10,000 or imprisonment up } \\
\text { to 5 years or both. }\end{array}$ \\
&
\end{tabular}

18 Dr. Rohani Abdul Rahim, Muhammad Afiq bin Ahmad Tajuddin, and Kamaruddin bin Hj. Abu Bakar, 'Combating Smuggling in Persons: A Malaysia Experience', SHS Web of Conferences, 18 (2015) $<$ https://doi.org/10.1051/shsconf/20151801004>. 
Section Persons who enter and stay in Malaysia 6(1)(c) unless in possession of a valid Pass lawfully issued to him to enter Malaysia

\section{Section 8 Prohibited Immigrants}

Section 9 Enter and stay in Malaysia after his/her Pass or Permit cancelled by the

Director-General of Immigration Department

Section 15 Stay in Malaysia after his/her Permit or Certificate cancelled or after the expiration of the period

Regulation Contravenes or fails to comply with any 39(b), Immigration Regulations 1963 instruction endorsed on, any Pass, Permit, or Boundary Pass on conviction, be liable to a fine not exceeding ten thousand ringgit or to imprisonment for a term not exceeding five years or to both, and shall also be liable to whipping of not more than six strokes Fine up to RM10,000 or imprisonment up to 5 years or both

Fine up to RM10,000 or imprisonment up to 5 years or both

Fine up to RM10,000 or imprisonment up to 5 years or both

Liable on conviction to a term of imprisonment not exceeding six months or to a fine not exceeding RM1,000 or to both such imprisonment and fine

Sources: Immigration Act 1959/1963 (Act 155)

For similar reason, in order to prevent trespass by illegal migrants, employers can be sanctioned for employing illegal migrants whom are not in possession of a valid pass. This is provided in Section 55B, Immigration Act 1959/1963 (Act 155) that states:

“(1) Any person who employs one or more persons, other than a citizen or a holder of an Entry Permit who is not in possession of a valid Pass shall be guilty of an offence and shall, on conviction, be liable to a fine of not less than ten thousand ringgit but not more than fifty thousand ringgit or to imprisonment for a term not exceeding twelve months or to both for each such employee. (2) A Pass lawfully issued to any person shall cease to be a valid Pass when any of its terms and conditions is contravened. (3) Where, in the case of an offence under subsection (1), it is proved to the satisfaction of the court that the person has at the same time employed more than five such employees that person shall, on conviction be liable to imprisonment for a term of not less than six months but not more than five years and shall also be liable to whipping of not more than six strokes. (4) For the purposes of this section a person performing any act normally performed by an employee in a place of employment whether or not for payment shall be presumed, unless the contrary is proved, to have been employed. (5) Where the offence under subsection (1) has been committed by a body corporate, any person who at the time of the commission of the offence was a member of the board of directors, a manager, a secretary or a person holding an office or a position similar to that of a manager or secretary of the body corporate shall be guilty of that offence and shall be liable to the same punishment to which the body corporate is liable under subsection (1) or (3)."

Therefore every citizen needs to be aware of illegal migrants existence and they have to play their role to report them and their activities to enforcers to prevent forest trespassing by illegal migrants in Sabah.

\section{CONCLUSION}

In conclusion, problems on forest trespass by foreign migrants in Sabah should not be taken lightly. It also involves public order and national security. ${ }^{19}$ The Sabah National Security Council is targeting to deport more than 13000 undocumented immigrants this year. ${ }^{20}$

19 Azizah Kassim and Ragayah Hj. Mat Zin, 'Irregular Migrants and the Law', Philippine Journal of Development, XXXVIII.1 \& 2 (2011), 87-104.

20 'Sabah NSC Targeting Deportation of Over 13,000 Immigrants This Year', Nation, 2020 <https://www.thestar.com.my/news/nation/2020/02/05/sabah-nsc-targeting-deportation-of-over-13000immigrants-this-year> [accessed 5 February 2020]. 
Therefore, a thorough study on the enforcement of the relevant legislation needs to be done to foresee every way as to how the trespassers could evade the legal enforcements and legal provisions that are meant to prevent illegal trespassing and exploitation of Sabah forest resources. The corporation between various enforcement agencies such as Eastern Sabah Security Command (ESSCOM), The Malaysian Royal Police, Malaysia Arm Forces, The Malaysian Maritime Enforcement Agency (MMEA) (Malaysian Coast Guard) and the Immigration Department is essential to overcome this issue efficiently. It is also crucial that the locals are aware of the need to preserve and sustain forest and wildlife ecology and forest resources for future generations. Any attempt to trespass the Sabah forest need to be alert to the authorities immediately. Public officials and the interested parties also need to be cautioned of their responsibility and duty to care for the forest sustainability, and corruptions for personal gains have to be avoided. The efforts to curb deforestation and prevent the illegal entry of foreign migrants should be regarded as a shared responsibility and support to all government's efforts to reduce the numbers of forest trespass cases soon.

\section{REFERENCES}

Anderson, Joseph Trawicki, 'Managing Labour Migration in Malaysia: Foreign Workers and The Challenges of "Control” Beyond Liberal Democracies', Third World Quarterly, 42.1 (2021), 86-104

Board, National Population and Family Development, Laporan Kajian Pekerja Indonesia Di Bahagian Tawau, Sabah (Kuala Lumpur, Malaysia: National Population and Family Development Board, 2014)

Carvalho, Martin, Hemananthani Sivandam, Rahimy Rahim, and Tarrence Tan, 'Xavier: Govt Considering Stiffer Penalties for Illegal Trespassing, Unlawful Possession of Forest Produce', Nation, 2019 <https://www.thestar.com.my/news/nation/2019/12/04/xaviergovt-considering-stiffer-penalties-for-illegal-trespassing-unlawful-possession-of-forestproduce> [accessed 4 December 2019]

Department, Sabah Forestry, 'Annual Report 2018' (Malaysia: Sabah, 2018) <http://myagric.upm.edu.my/id/eprint/16241/1/ar2017.pdf>

\begin{tabular}{c}
- 'Anual \\
\hline <http://myagric.upm.edu.my/id/eprint/16241/1/ar2017.pdf $>$
\end{tabular}

Dollah, Ramli, and Ahmad Mosfi Mohamad, 'Malaysia-Indonesia Barter Trade: Opportunities and Challenges', JATI-Journal of Southeast Asian Studies, 12 (2007), 83-106

Junaidi, Aiman Aizuddin, Salawati Mat Basir, Rohani Abdul Rahim, Mohd Shukor Abdul Mumin, and Muhammad Afiq Ahmad Tajuddin, 'Trafficking In Persons Laws And Border Control Challenges In Malaysia: Asean Discourse' (Sciendo, 2019), pp. 27-35 <https://doi.org/10.1515/9783110678666-006>

Juppenlatz, Morris, Cities in Transformation: The Urban Squatter Problem of the Developing World (University of Queensland Press, 1970)

Kanapathy, and Vijayakumari, Controlling Irregular MIgration: The Malaysian Experience (International Labour Organization, 2008)

Kassim, Azizah, 'The Unwelcome Guests: Indonesian Immigrants and Lamaysian Public 
Responses', Japanese Journal of Southeast Asian Studies, 25.265-278 (1987) <https://kyoto-seas.org/pdf/25/2/250205.pdf>

Kassim, Azizah, and Ragayah $\mathrm{Hj}$. Mat Zin, 'Irregular Migrants and the Law', Philippine Journal of Development, XXXVIII.1 \& 2 (2011), 87-104

Kaur, Amarjit, Labour in Malaysia: Flexibility, Policy-Making and Regulated Borders, ed. by Meredith L Weiss (Oxford, United Kingdom: Routledge, 2015) <https://hdl. handle.net/1959.11/17636>

McConville, Mike, and Wing Hong Chui, Research Methods for Law, 2nd edn (United Kingdom: Edinburgh University Press Ltd, 2017)

Rahim, Dr. Rohani Abdul, Muhammad Afiq bin Ahmad Tajuddin, and Kamaruddin bin Hj. Abu Bakar, 'Combating Smuggling in Persons: A Malaysia Experience', SHS Web of Conferences, 18 (2015) <https://doi.org/10.1051/shsconf/20151801004>

'Sabah NSC Targeting Deportation of Over 13,000 Immigrants This Year', Nation, 2020 $<$ https://www.thestar.com.my/news/nation/2020/02/05/sabah-nsc-targeting-deportation-ofover-13000-immigrants-this-year> [accessed 5 February 2020]

Sert, Deniz, 'Harald Kleinschmidt (Ed), Migration, Regional Integration and Human Security: The Formation and Maintenance of Transnational Spaces', Millennium: Journal of International Studies, $35.3 \quad$ (2007), 781-84 <https://doi.org/10.1177/ 03058298070350030710>

Suter, Megan K, Kristin A Miller, Ike Anggraeni, Kristie L Ebi, Edward T Game, Jennifer Krenz, and others, 'Association Between Work in Deforested, Compared to Forested, Areas and Human Heat Strain: An Experimental Study in A Rural Tropical Environment', Environmental Research Letters, 14.8 (2019), 084012

Tacconi, Luca, Illegal Logging: Law Enforcement, Livelihoods and The Timber Trade (London: Earthscan Forest Library, 2007)

Webley, Lisa, Qualitative Approaches To Empirical Legal Research, ed. by Peter Cane and Herbert M. Kritzer, 1st edn (Oxford University Press, 2010) $<$ https://www.researchgate.net/publication/259339842_Chapter_38_Qualitative_Approach es_to_Empirical_Legal_Research> 